\title{
Zrównoważony marketing w zrównoważonym świecie - cz. 1
}

\section{Sustainable marketing in a sustainable world — part 1}

\author{
doc. dr Jacek Kamiński \\ Państwowa Szkoła Wyższa im. Papieża Jana Pawła Il w Białej Podlaskiej \\ ORCID: 0000-0001-7376-8190 \\ e-mail: jacek_kaminski@vp.pl
}

\begin{abstract}
W powszechnym odbiorze dominuje pogląd, że marketing i zrównoważony rozwój to pojęcia od siebie dość odległe. Tymczasem związek marketingu i zrównoważonego rozwoju jest wyjątkowo silny. Wynika z funkcji pełnionych przez marketing w gospodarce i społeczeństwie, polegających na kojarzeniu dóbr i potrzeb na rynku oraz aktywności w sferze kreowania i zaspokojenia pragnień i oczekiwań konsumentów w celu osiągania przez nich satysfakcji oraz podniesienia jakości życia. Koncepcją, która najpełniej odzwierciedla zainteresowanie marketingu zrównoważonym rozwojem oraz otwiera marketing na dorobek nauk o zrównoważeniu (sustainable science) jest zrównoważony marketing (sustainable arketing/sustainability marketing). Celem artykułu jest scharakteryzowanie tej marketingowej koncepcji oraz wyjaśnienie, w jakim zakresie wpływa ona na przedefiniowanie założeń tradycyjnego marketingu. Artykuł składa się z dwóch części. W pierwszej wyjaśniono, dlaczego marketing nie może być obojętny wobec kwestii środowiskowych, omówiono bariery tego zainteresowania oraz związaną z nim tradycję. W drugiej przedstawiono założenia zrównoważonego marketingu, prezentując go jako koncepcję makromarketingową, która wymaga zasadniczego przedefiniowania tradycyjnego marketingu oraz wprowadzenia istotnych zmian w zarządzaniu marketingowym. W zakończeniu sformułowano wnioski wynikające $\mathrm{z}$ przeprowadzonej analizy, dotyczące miejsca, specyfiki i znaczenia problematyki środowiskowej w nauce o marketingu.
\end{abstract}

\section{Keywords}

marketing, zrównoważony marketing, teoria marketingu, historia myśli ekonomicznej, ekonomia środowiskowa

There is a common perception of marketing and sustainable growth to be two concepts which are rather distant from one another. Yet, the relationship between marketing and sustainable growth is remarkably strong. It stems from the functions fulfilled by marketing in the economy and in the society, which consist of matching the goods and the demands on the market as well as activities in the area of creation and fulfillment of desires and expectations of consumers in order to reach their satisfaction and lift their quality of life. The concept which reflects the interest of marketing with a sustainable growth most fully and opens marketing up to the achievements of sciences about sustainability (sustainable science) is sustainable//sustainability marketing. The objective of the article is to characterize this marketing concept and explain in what scope it impacts redefining the assumptions of traditional marketing. The article consists of two parts. The first part encompasses explanations as to why the marketing may be indifferent towards environmental matters, further to the analysis of barriers of this interest and the tradition related to them. The second part presents the assumptions of sustainable marketing, presenting it as the macro-marketing concept which requires fundamental redefining of traditional marketing and introducing significant changes in the marketing management. Conclusions were drawn in the final part which stem from the carried out analysis concerning the place, the specificity and the meaning of the environmental problem in marketing science.

Slowa kluczowe

marketing, sustainable marketing, marketing theory, history of economic thought, environmental economics

JEL: B0, M3, Q5

Str. 3-15 


\section{Bibliografia}

Antil, J. H. (1984). Socially responsible consumers: Profile and implications for public policy. Journal of Macromarketing, 4(2), 18-39. https://doi.org/10.1177/027614678400400203

Boddewyn, J. (1966). A construct for comparative marketing research. Journal of Marketing Research, 3(2), $149-153$. https://doi.org/10.2307/3150203

Boulding, K. (1966). The economics of the coming spaceship Earth. W: H. Jarrett (red.) Environmental Quality in a Growing Economy (3-14). Baltimore: John Hopkins Press.

Daly, H. E. (1991). Steady-State Economics. New York: Island Press.

Dawson, L. M. (1971). Marketing science in the Age of Aquarius. Journal of Marketing, 35(3), 66-72. https://doi.org/10.1177/002224297103500311

Dixon, D. F. i Wikinson, I. F. (1984). An alternative paradigm for marketing theory. European Journal of Marketing, 18(3), 40-50. https://doi.org/10.1108/EUM0000000004780

Dominguez, G. S. (1974). Marketing in a Shortage Economy. New York: AMACOM.

Fiedor, B. i Graczyk, A. (2016). Normatywny i pozytywny charakter kategorii rozwoju trwałego. Optimum. Studia Ekonomiczne, 1(79), 3-13. https://doi.org/10.15290/ose.2016.01.79.01

Fisk, G. (1973). Criteria for a theory of responsible consumption. Journal of Marketing, 37, $24-31$. https://doi.org/10.2307/1250047

Fisk, G. (1974). Marketing and the Ecological Crisis. London: Harper and Row.

Górka, K. i Łuszczuk, M. (2017). Badania nad rozwojem trwałym w polskich ośrodkach naukowych. Optimum. Studia Ekonomiczne, 1(85), 20-36. https: //doi.org/10.15290/ose. 2017.01.85.02

Hardin, G. (1968). The tragedy of commons. Science, 162, 1243-1248. http://doi.org/10.1126/science. 162.3859.1243

Henion, K. (1976). Ecological Marketing. Columbus: Grid Publication.

Jones, P., Clarke-Hill, C., Comfort, D. i Hiller, D. (2008). Marketing and sustainability. Marketing Intelligence and Planning, 26(2), 123-130. https://doi.org/10.1108/02634500810860584

Kamiński, J. (2017). O systemowym podejściu do marketingu. W sześćdziesiątą rocznicę opublikowania książki W. Aldersona Marketing Behavior and Executive Action (1957). Marketing i Rynek, (5), 10-21.

Kilbourne, W., McDonagh, P. i Prothero, A. (2018). Sustainable consumption, consumer culture and the politics of a megatrend. W: O. Kravets, P. Maclaran, S. Miles i A. Venkaters (red.), The SAGE Handbook of Consumer Culture (478-498). London: Sage Publications.

Kłeczek, R. (2013). Efektywność i skuteczność działań ekologicznych w marketingu: problem decyzyjny i badania empiryczne. Rocznik Ochrony Środowiska, (15), 2829-2839.

Krzyżanowska, M. i Wrzosek, W. (2009). Ograniczenia popytowe a marketing. Marketing i Rynek, (5), $2-6$.

Kotler, P. i Levy, S. (1971). Demarketing. Yes, demarketing. Harvard Business Review, 49(6), 74-80.

Kuhn, T. (1968). Struktura rewolucji naukowych. Warszawa: PWN.

Layton, R. A. (2015). Formation, growth, and adaptive change in marketing systems. Journal of Macromarketing, 33(1), 302-319. http://doi.org/10.1177/0276146714550314

Layton, R. A. i Grossbart, S. (2006). Macromarketing: Past, present, and possible future. Journal of Macromarketing, 26(2), 193-213. http://doi.org/10.1177/0276146706294026

Lazer, W. (1969). Marketing's changing social relationships. Journal of Marketing, 33 (1), 3-9. http://doi.org/ $10.2307 / 1248739$

Lee, D. J., Sirgy, M. J., Larsen, V. i Wright, D. (2002). Developing a subjective measure of consumer well-being. Journal of Macromarketing, 22(2), 158-169. https://doi.org/10.1177/0276146702238219

Meade, W. K. i Nason, R. W. (1991). Toward a unified theory of macromarketing: A systems theoretic approach. Journal of Macromarketing, 11(2), 72-82. https://doi.org/10.1177/027614679101100208

Meadows, D. i Randers, J. (1972). The Limits to Growth. New York: Universe Books.

Mittelstaedt, J. D., Killbourne W. E. i Shultz C. J. II (2015). Macromarketing approaches to thought development in positive marketing: Two perspectives on research agenda for positive marketing scholars. Journal of Business Research, 68(12), 2513-2516. https://doi.org/10.1016/j.jbusres.2015.06.038

Peattie, K. (2007). Sustainable marketing: Marketing re-thought, re-mixed and re-tooled. W: M. Saren, P. Maclaran, Ch. Goulding, R. Eliot, A. Shankar i M. Catterall (red.), Critical Marketing: Defining the Field. Oxford: Elsevier.

Peattie, K. i Belz, F.-M. (2010). Sustainability marketing — an innovative conception of marketing. Marketing Review of St. Gallen, 27(5), 8-15. https://doi.org/10.1007/s11621-010-0085-7

Shapiro, S. J. (1978). Marketing in conserver society. Business Horizons, (April), 3-13. https://doi.org/10.1016/00076813(78)90040-X

Schwarzkopf, S. (2018). Consumer-Citizens: Markets, Marketing and the Making of 'choice'. W: O. Kravets, P. Maclaran, S. Miles i A. Venkaters (red.), The SAGE Handbook of Consumer Culture (435-452). London: Sage Publications. 
Van Dam, Y. K. i Apeldoorn, P. A. C. (1996). Sustainable marketing. Journal of Macromarketing, (Fall), 45-56. https://doi.org/10.1177/027614679601600204

Wackernagle, M. i Rees, W. (1998). Our Ecological Footprint: Reducing Human Impact on the Earth. New York: New Society Publishers.

Weiss, E. B. (1971). The coming change in marketing; from growthmania to shrinkmanship. Advertising Age, l(February). Wymer, W. i Polonsky, M. J. (2015). The limitations and potentialities of green marketing. Journal of Nonprofit \& Public Sector Marketing, 27(3), 239-262. https://doi.org/10.1080/10495142.2015.1053341 